\title{
PERJANJIAN KAWIN YANG TIDAK DIDAFTARKAN DALAM PERKAWINAN CAMPURAN
}

\author{
Desak Putu Kania Pratiwi, I Nyoman Putu Budiartha, Desak Gde Dwi Arini \\ Fakultas Hukum Universitas Warmadewa, Denpasar, Bali, Indonesia
}

\begin{abstract}
Abstrak
Manusia secara kodrat dilahirkan sebagai mahluk individu dan sosial, ditakdirkan untuk hidup mempunyai pasangan hidup hingga memiliki keturunan dan membentuk keluarga atau rumah tangga yang bahagia. Dalam suatu perkawinan baik perkawinan antar negara atau berbeda kewarganegaraan memiliki permasalahan hukum mengenai ketidakadilan dalam menjalankan hak dan kewajiban dari pihak suami atau pihak istri. Adanya perjanjian kawin sangat penting untuk melindungi hak dan kewajiban tersebut. Penelitian ini menerangkan bagaimana kedudukan hukum perjanjian kawin dalam perkawinan campuran dan mengetahui akibat hukum suatu perjanjian kawin yang tidak didaftarkan. Penelitian ini menggunakan jenis penelitian hukum normatif dan analisis menggunakan metode interprestatif, sistematis dan argumentatif. Sumber data dalam penelitian ini adalah sumber bahan hukum primer dan sekunder. Hasil penelitian ini adalah kedudukan hukum perjanjian kawin dalam perkawinan campuran yaitu memberikan kepastian hukum dalam melakukan perbuatan hukum atas harta yang berada pada penguasaannya baik harta bawaan maupun harta yang diperoleh setelah atau selama perkawinan, serta memberikan perlindungan atas hak dan kewajiban masing-masing pihak dalam pengurusan rumah tangga. Kedua, akibat hukum suatu perjanjian kawin yang tidak didaftarkan dalam perkawinan campuran yaitu perjanjian kawin tetap mengikat kedua belah pihak, akan tetapi perjanjian kawin tersebut tidak mengikat pihak ketiga apabila ada perbuatan hukum yang dilakukan terhadap harta benda yang berada pada penguasaannya masing-masing.
\end{abstract}

Kata Kunci: Perjanjian; Perjanjian kawin; Perkawinan campuran

\begin{abstract}
Humans are naturally born as individual and social beings, destined to have a life partner to have offspring and made a happy family. In marriages, both marriages between countries or different nationalities have legal problems regarding injustice in exercising the rights and obligations of the husband or wife. The existence of a marriage promise is very important to protect these rights and obligations. This research explains how legal the status of the marriage agreement in marriage and the responsiveness the law of an agreement that is not registered. This research used normative legal research and analysis uses interpretative, systematic, and argumentative methods. Sources of data in this study are sources of primary and secondary legal materials. The result of the research is the legal position of the marriage agreement in mixed marriages, which is to provide legal certainty in carrying out legal actions on assets under control, either inherited or acquired after or during marriage, as well as providing protection for the rights and obligations of each party in managing the house stairs. Second, the legal consequence of a marriage agreement that does not register in a mixed marriage is that the marriage agreement is still binding on both parties, but the marriage agreement does not bind a third party or there is a legal action committed against the property under their respective control.
\end{abstract}

Keywords: Agreement; Marriage agreement; Blended marriage

\section{PENDAHULUAN}

Manusia adalah makhluk sosial yang tidak bisa hidup sendiri yang tidak dapat mencapai segala sesuatu dengan mudah tanpa bantuan dari orang lain (Inah, 2013). Setiap manusia dikodratkan untuk hidup mempunyai pasangan, memiliki keturunan dan berkeluarga. Keluarga adalah suatu kesatuan dimana terdiri dari suami (ayah), istri (ibu) serta anak-anaknya yang hidup bersama dan menetap pada satu rumah atau tempat tinggal. Tinggal menetap pada satu tempat tinggal atau rumah terjadi akibat 
dari adanya suatu perkawinan dan karena mempunyai suatu ikatan hubungan darah dengan anak. Perkawinan memiliki konsep yaitu hubungan yang mengikat kedua pihak dengan kemauan bersama yang sungguh-sungguh antara seorang pria sebagai suami dan wanita sebagai istri yang hidup bersama (Ap, 2013). Setiap perkawinan memiliki suatu keinginan untuk dapat membangun sebuah keluarga atau rumah tangga yang baik dan sejahtera. Perkawinan tidak mengenal jangka waktu tertentu kecuali ada dari salah satu pihak yaitu antara pihak dari suami maupun pihak dari istri yang tutup usia.

Bentuk dari pelaksanaan HAM Pasal 28 B UUDNRI 1945, maka segala jenis perkawinan sah-sah saja, selama mengikuti aturan tersebut, termasuk pula dengan perkawinan campuran. Banyaknya warga dari Negara Asing (WNA) yang berkunjung untuk berlibur maupun hanya untuk menetap dalam jangka waktu sebentar atau hanya sementara di Negara Indonesia, mempunyai hak-hak perdata yang telah dijamimn oleh peran peraturan perundang-undangan antara lain yaitu mempunyai hak untuk melangsungkan perkawinan dan bisa menunjuk WNI (Warga Negara Indonesia) selaku pasangannya (Supramono, 2012). Perjanjian kawin berisi mengenai segala hal dan tidak melanggar undang-undang, agama dan kesusilaan misalnya mengenai hak dan kewajiban sebagai seorang suami serta sebagai seorang istri, hak dan kewajiban sebagai suami dan istri, penyatuan dari aset atau hartakekayaan, penguasaan, pengawasan dan perawatan harta kekayaan suami dan istri.

Putusan MK No. 69/PUU-XIII/2015 selanjutnya mengubah penafsiran mengenai pelaksanaan perjanjian kawin yang sebelumnya dibuat sebelum terjadinya perkawinan dengan memperbolehkan juga pembuatan perjanjian kawin sepanjang perkawinan itu berlangsung. Keadaan ini dapat menjadi suatu permasalahaan hukum tatkala putusan dari Mahkamah Konstitusi No.69/PUU-XIII/2015 tersebut dihadapkan dengan ketentuan Pasal 186 Kitab Undang-Undang Hukum Perdata (selanjutnya disebut KUH Perdata) yang mengatur mengenai proses dari pembuatan atau penyusunan suatu perjanjian perkawinan sesudah perkawinan tersebut dilaksanakan (pemisahaan harta) dimana perlu memperoleh suatu penetapan dari pengadilan terlebiih dahulu. Dalam penetapan itu termuat suatu perintah dari pihak pengadilan terhadap pihak Catatan Sipil guna melaksanakan pendaftaran suatu perjanjian perkawinan (Paramitra, 2017). Selain perihal penafsiran dibuatnya perjanjian kawin yang dapat dilaksanakan sebelum waktu dilangsungkannyamaupun selama didalam suatu ikatan jalinan perkawinan, Putusan dari MK (Mahkahmah Konstitusi) No. 69/PUU-XIII/2015menambahkan bahwa peran dari notaris pada pengajuan pengesahan dari perjanjian perkawinan. Perbedaan Putusan dari MK (Mahkahmah Konstitusi) No. 69/PUU-XIII/2015dengan Pasal 29 UU Perkawinan secara tidak langsung dapat berpengaruh terhadap kewenangan pegawai pencatat nikah dalam proses pengesahannya. Perkawinan campuran yang dilaksanakan menurut hukum Indonesia dan dilangsungkan sebelum berlakunya Undang-Undang Nomor 1 Tahun 1974. Kambey, (2017) mengungkapkan bawwa Perjanjian perkawinan merupakan persetujuan perjanjian secara tertulis yang dibuat oleh pasangan calon suami istri. Peneliti selanjutnya mengungkapkan bahwa terjadi percampuran harta karena dalam KUHPerdata tidak mengenal pemisahaan penguasaan harta bawaan sehingga terhadap kepemilikan hak milik atas tanah wajib dilepaskan dalam jangka waktu 1 (satu) tahun atau tanah tersebut jatuh kepada negara (Pratama, 2018). Penelitian ini menerangkan bagaimana kedudukan hukum perjanjian kawin dalam perkawinan campuran dan mengetahui akibat hukum suatu perjanjian kawin yang tidak didaftarkan dalam agenda pernikahan campuran.

\section{METODE PENELITIAN}

Penelitian ini menggunakan jenis penelitian hukum normatif dan analisis menggunakan metode interprestatif, sistematis, dan argumentatif. Sumber data dalam penelitian ini adalah sumber bahan hukum primer dan sekunder. Sumber bahan hukum primer adalah suatu sumber bahanhukum yang sifatnya terikat yang dapat berupa aturan, norma, landasan dasar maupun peraturan yang sifatnya mengikat. Sumber bahan hukum sekunder adalah suatu sumber bahan hukum yang dapat memberikan suatu penjabaran tentang bahan hukum primer. Sumber bahan hukum primer yang digunakan dalam penelitian ini, antara lain: referensi literatur yang signifikan dengan permasalahan atau topik yang sedang dibahas dalam penelitian ini, yang dapat berupa literatur hukum, pendapat dari ahli maupun para sarjana serta jurnal hukum yang terkait dengan topik dari penelitian ini. 


\section{HASIL DAN PEMBAHASAN}

\section{Kedudukan Hukum Perjanjian Kawin dalam Perkawinan Campuran}

Akibat dari suatu perkawinan antara suami dan istri menimbulkan adanya hak dan kewajiban dalam mengatur/mengelola rumah tangga serta tanggungjawab sosial kemasyarakatan. Perjanjian kawin harus didaftarkan karena memiliki kedudukan penting bagi pihak suami maupun istri dalam menjaga kedamaian rumah tangga, dan apabila terjadi permasalahan dalam rumah tangga seperti terjadinya suatu pertengkaran yang berakibat diakhirinya perkawinan, maka perjanjian kawin berfungsi sebagai media penyelesaian dalam pengaturan harta kekayaan dan hak asuh anak serta tanggungjawab masing-masing.Tidak dibuatnya perjanjian kawin sebelum atau pada saat perkawinan dilaksanakan dapat memicu sengketa harta bersama antara suami dan istri. Demikian juga apabila salah satu pihak baik itu suami atau istri tidak melaksanakan atau menempati perjanjian kawin yang dibuat, maka pihak lain/ketiga yang tersangkut berhak untuk melaporkan atau menuntut ke Pengadilan baik mengenai perjanjian yang dibuat oleh para pihak maupun tuntutan ganti rugi.

Perjanjian kawin yaitu suatu perjanjian antara seorang laki-laki dan perempuan yang melaksanakan suatu perkawinan baik sebelum atau pada saat suatu perkawinan berlangsung. Berdasarkan pengertian perjanjian dalam hal ini dihubungkan dengan perjanjian kawin bahwa pihak yang akan melakukan suatu perjanjian kawin didasari dengan beritikad baik untuk membuat sebuah kesepakatan dalam membangun rumah tangga. Janji-janji tersebut diwujudkan atau dilaksanakan sesuai dengan hukum adat dan kepercayaan dari kedua pihak. Perjanjian kawin dibuat tidak hanya untuk pasangan antar Negara, tetapi berlaku juga pada berlainan kewarganegaraan atau biasa disebut dengan perkawinan campuran. Perjanjian kawin sangat penting untuk melindungi dan memperjelas hak dan kewajiban kedua belah pihak, baik selama perkawinan berlangsung maupun akibat-akibat hukum setelah perkawinan putus karena perceraian atau kematian. Dengan adanya perjanjian kawin akan menjamin hak dan kewajiban (Istrianti \& Priambada, 2015). Pada perjanjian kawin semua bentuk dan hal-hal yang berisi janji-janji dari para pihak akan menjadi UU hanya bagi para pihak yang membuatnya. Hal ini termuat dalam pasal 1338 ayat (1) KUH Perdata. Syarat untuk membuat perjanjian kawin, antara lain yakni:

1. Perjanjian kawin dibuat oleh para pihak sebelum atau pada saat perkawinan dilangsungkan;

2. Dibuat atas kesepakatan bersama;

3. Dibuat secara tertulis dalam bentuk akta otentik di hadapan Notaris;

4. Dicatatkan/ didaftarkan di Kantor Pegawai Pencatat Perkawinan di Kantor Sipil.

Kecakapan dalam membuat perjanjian kawin perlu juga diperhatikan karena tolok ukur usia pada setiap peraturan perundang-undangan berbeda. Menurut KUHPerdata yang cakap untuk membuat suatu perjanjian yaitu sudah berusia 21 tahun (Pasal 330 KUHPerdata) atau telah kawin, sedangkan menurut UU No 2 Tahun 2014 perubahan atas UU No 30 Tahun 2004 tentang Jabatan Notaris cakap untuk membuat perjanjian kawin yaitu berusia 18 tahun Pasal 39 ayat (1), akan tetapi menurut ketentuan UU Perkawinan mensyaratkan bahwa perkawinan hanya diizinkan jika pihak pria sudah mencapai umur Sembilan belas tahun dan pihak wanita sudah mencapai umur enam belas tahun.

Perjanjian kawin juga diatur pada Pasal 29 dalam UU Perkawinan. Dari Pasal 29 UU Perkawinan tersebut memiliki makna yakni:

1. Perkawinan kawin dibuat berdasarkan kesepakatan janji-janji dari pihak suami istri pada saat sebelum atau pada saat perkawinan berlangsung;

2. Dibuat dihadapan Notaris dengan dibuat secara notariil;

3. Dapat dirubah dengan persetujuan bersama sepanjang tidak merugikan pihak ketiga;

4. Dicatat di Kantor Pencatatan Sipil.

Pasca dikeluarkannya Putusan MK terjadi perubahan dalam pembuatan perjanjian kawin yang mana melangsungkan perkawinan campuran dengan tanpa membuat perjanjian kawin terlebih dahulu antara seorang Warga Negara Indonesia dengan Warga Negara Asing. Mahkamah Konstitusi dalam pertimbangan hukumnya menentukan bahwa, ketentuan yang berlaku pada saat ini hanya mengatur perjanjian perkawinan yang dibuat sebelum dilangsungkan perkawinan, tetapi dalam kenyataannya bahwa pihak suami atau pihak istri merasakan adanya kebutuhan untuk membuat perjanjian kawin selama melangsungkan perkawinan.

Berkaitan dengan dibuatnya perjanjian kawin pada perkawinan campuran status anak dalam hal berkewarganegaraan harus jelas dicantumkan pada salah satu pasal dalam perjanjian kawin tersebut dan status anak tidak memiliki 2 (dua) kewarganegaraan yang berbeda. Demikian juga Harta 
kekayaan yang telah maupun akan diperoleh baik dalam bentuk benda bergerak seperti kendaraan dan benda maupun benda tidak bergerak seperti hak atas tanah dengan status kepemilikan atas nama pihak yang berkewarganegaraan Indonesia.

Menurut Sembiring, (2016) Ketentuan-ketentuan harta benda dalam perkawinan diantaranya adalah:

1. Harta Bersama adalah suatu harta yang diterima selama perkawinan berlangsung dimana selama perkawinan tersebut dilangsungkan hingga perkawinan tersebut berakhir maupun putusnya suatu perkawinan yang diakibatkan dari adanya perceraian, kematian serta adanya putusan dari pengadilan;

2. Harta bawaan adalah suatu harta yang dikuasai oleh masing-masing pemiliknya yaitu pihak suami dan juga pihak istri. Pihak suami maupun pihak istri masing-masing berhak sepenuhnya melakukan suatu perbuatan hukum tentang harta benda;

3. Harta perolehan adalah harta milik masing-masing suami istri yang dimilikinya Sesudah pasangan suami dan istri tersebut berada dalam hubungan perkawinan.

Sesuai ketentuan dalam Putusan MK(Mahkamah Konstitusi) pada Pasal 29 ayat (4) Berdasarkan ketentuan Pasal 29 Ayat (4) Putusan MK, perjanjian kawin bisa perihal harta perkawinan maupun perjanjian lainnnya, sehingga dari para pihak yang membuatnya bisa untuk bebas menentukan bagaimana isi dari perjanjian kawin tersebut.

\section{Akibat Hukum Perjanjian Kawin yang Tidak Didaftarkan dalam Perkawinan Campuran}

Perjanjian kawin pada dasarnya mengatur tentang harta kekayaan yang diperoleh sebelum dan pada saat perkawinan berlangsung. Dengan adanya perjanjian kawin, maka harta bawaan pihak suami dan istri tetap menjadi milik masing-masing. Perjanjian kawin mempunyai tujuan dan manfaat yang baik yaitu sebagai tindakan preventif apabila terjadi perceraian, karena dengan dibuatnya perjanjian kawin akan mempermudah pembagian harta bersama atau harta gono-gini yang didapatkan selama perkawinan (Putri dkk., 2019). Dalam hal persyaratan perjanjian kawin tidak diatur secara jelas oleh UU Perkawinan, oleh karena itu dalam pembuatan perjanjian kawin masih mengacu pada KUH Perdata. KUH Perdata hanya menetapkan beberapa ketentuan yang disyaratkan untuk membuat perjanjian kawin yang tercantum dalam pasal 1320 KUH Perdata. Pada pembuatan dan mulai berlakunya perjanjian kawin, pasal 147 KUH Perdata menentukan bahwa suatu perjanjian kawin harus dibuat dengan akta Notaris. Hal itu dimaksudkan agar perjanjian kawin tersebut dapat dituangkan dalam bentuk akta otentik. Berkaitan dengan akibat hukum pada perjanjian kawin yang tidak didaftarkan akan berpengaruh terhadap para pihak yang membuatnya termasuk pihak ketiga dan memiliki konsekuensi tersendiri.

Akibat dari adanya Putusan MK ini yakni dalam Pasal 12 PP No. 9 Tahun 1975 tentang Pelaksanaan UU No.1 Tahun 1974 Tentang Perkawinan, telah menegaskan bahwa perjanjian kawin haruslah tercantum dalam suatu akta perkawinan. Berdasarkan pada hasil wawancara dengan salah satu informan di bagian perkawinan pada Kantor pencatatan sipil kota Denpasar bahwa tidak adanya suatu batasan waktu dalam melaporkan atau mencatatkan perjanjian kawin tersebut. Dalam hal melakukan pencatatan dari perjanjian kawin khususnya pada perkawinan campuran diharuskan menyantumkan suatu akta perkawinan. Perkawinan perjanjian tersebut tetap berlaku namun hanya bagi kedua belah pihak saja, akan tetapi apabila tidak didaftarkan maka perjanjian kawin tersebut tidak berlaku bagi pihak ketiga dan tidak pernah bahwa perjanjian kawin tersebut ada bagi kantor catatan sipil.

Sesuai atas asas lahirnya suatu perjanjian yaitu asas konsensualisme yang menyatakan bahwa perjnjian lahir sejak saat tercapainya suatu kata sepakat diantara para pihak, maka perjanjian kawin tersebut bersifat mengikat bagi para pihak yang membuatnya saat keduanya telah sepakat tentang perjanjian yang telah dibuat tersebut. Maka walaupun didaftarkan atau tidak dilaporkan, perjanjian kawin tersebut sifatnya tetap mengikat bagi para pihak yang membuatnya. Konsekuensi hukum pada pihak ketiga apabila perjanjian kawin tersebut tidak didaftarkan kepada pegawai di bagian pencatatan perkawinan pada kantor sipil, maka perjanjian kawin tidak mempunyai kekuatan hukum untuk mengikat pihak ketiga (Tutik, 2006). 


\section{SIMPULAN DAN SARAN}

\section{Simpulan}

Berdasarkan analisis data dapat disimpulkan bahwa Kedudukan hukum perjanjian kawin dalam perkawinan campuran yaitu memberikan kepastian hukum bagi para pihak dalam melakukan perbuatan hukum atas harta yang berada pada penguasaannya baik harta bawaan maupun harta yang diperoleh setelah atau selama perkawinan, serta memberikan perlindungan atas hak dan kewajiban masing-masing pihak dalam pengurusan rumah tangga, dan Akibat hukum suatu perjanjian kawin yang tidak didaftarkan dalam perkawinan campuran yaitu perjanjian kawin tetap mengikat kedua belah pihak, akan tetapi perjanjian kawin tersebut tidak mengikat pihak ketiga apabila ada perbuatan hukum yang dilakukan terhadap harta benda yang berada pada penguasaannya masing-masing.

\section{Saran}

Adapun yang bisa disarankan oleh peneliti yaitu pengaturan perundang-undangan perjanjian kawin khususnya dalam perkawinan campuran Pemerintah harus memberikan penjelasan agar memiliki kepastian hukum, dan mensosialisasikan terutama kepada pejabat yang berwenang yaitu Notaris dalam pembuatan akta perjanjian kawin. Notaris dalam pembuatan akta perjanjian kawin khususnya pada perkawinan campuran berkewajiban untuk memberitahukan pada para pihak agar segera setelah diterima salinan akta perjanjian kawin tersebut didaftarkan di Kantor Catatan Sipil

\section{DAFTAR PUSTAKA}

Ap, R. D. K. (2013). Kesetaraan Laki-Laki dan Perempuan dalam Hukum Perkawinan Islam. 8(2), 361-386. Inah, E. N. (2013). Peranan Komunikasi dalam Pendidikan. Jurnal Al-Ta'dib, 6(1), 176-188.

Istrianti, A., \& Priambada, E. (2015). Akibat Hukum Perjanjian Perkawinan yang Dibuat Setelah Perkawinan Berlangsung. Privat Law, 3(2), 84-92.

Kambey, E. E. (2017). Analisis tentang Perjanjian Perkawinan Ditinjau dari Putusan Mahkamah Konstitusi Nomor 69/PUU-XIII/2015. Lex Privatum, 5(9), 1-14.

Paramitra, E. (2017). Akibat Hukum Perjanjian Perkawinan yang Tidak Disahkan oleh Pegawai Pencatat Perkawinan. Jurnal Reporetorium, 4(2), 32-38.

Pratama, A. D. (2018). Keduduka Kepemilikan Hak atas Tanah dalam Perkawinan Campuran Tanpa Adanya Perjanjian Pisah Harta. 3(2), 247-263.

Putri, R. N., Judiasih, S. D., \& Lubis, N. anisa. (2019). Perlindungan Hukum terhadap Kreditor dan Upaya Notaris Membuat Perjanjian Perkawinan Setelah Perkawinan. Veritas et Justitia, 5(2), 464-491.

Sembiring, R. (2016). Hukum Keluarga Harta-Harta Benda dalam Perkawinan. Raja Grafindo Persada. Supramono, G. (2012). Hukum Orang Asing di Indonesia. Sinar Grafika.

Tutik, T. T. (2006). Pengantar Hukum Perdata di Indonesia. Prestasi Pustaka Publiser. 